\title{
Penerapan Metode Overview, Key Ideas, Read, Record, Recite, Review dan Reflect untuk Meningkatkan Kemampuan Membaca Pemahaman Siswa Sekolah Dasar
}

\author{
Ina Yati ${ }^{1}$, Herlina ${ }^{2}$, Syarifuddin ${ }^{3}$ \\ ${ }^{1}$ Program Studi Pendidikan Guru Madrasah Ibtidaiyah Fakultas Tarbiyah dan Keguruan Universitas Islam \\ Negeri Sultan Syarif Kasim Riau \\ e-mail: Inayati042@gmail.com
}

\begin{abstract}
ABSTRAK. This study aims to determine the improvement of elementary school students' reading comprehension skills through the application of overview, key ideas, read, record, recite, review and reflect methods. This research is motivated by the lack of students' ability to understand the reading text that is read. This research is a classroom action research. Data collection techniques in this study were observation, students' reading comprehension test and documentation. While the data analysis technique used is a qualitative descriptive analysis technique with a percentage. Based on research and data analysis that the application of overview, key ideas, read, record, recite, review and reflect methods can improve students' reading comprehension skills. This can be seen from the test results of students' reading comprehension before the action only reached an average of 58.42 with classical completeness of $42.85 \%$ or classified as poor. After applying the overview, key ideas, read, record, recite, review and reflect methods in the first cycle, the students' reading comprehension ability increased by an average of 72.28 with a classical completeness of $66.66 \%$ or quite good. In the second cycle, the results of students' reading comprehension increased by an average of 81.23 with classical completeness of $85.71 \%$ or classified as good. Thus it can be concluded that the overview, key ideas, read, record, recite, review and reflect methods can improve the reading comprehension ability of elementary school students.
\end{abstract}

Kata kunci: Method Overview, Key Ideas, Read, Record, Recite, Review and Reflect, Ability to Read Comprehension

\section{PENDAHULUAN}

Pembelajaran bahasa Indonesia diajarkan 4 aspek yaitu menyimak (listening skill), berbicara (speaking skill), membaca (reading skill) dan menulis (writing skill).Keempat aspek tersebut mempunyai peranan yang sangat penting dan saling mempengaruhi terhadap kemampuan berbahasa siswa.Salah satu aspek penting yang harus dikuasai oleh siswa adalah membaca (Sahati Kaban dan Tria Rutmila, 2015). Kemampuan membaca yang memadai dapat dicapai dengan pemahaman sehingga menunjukkan bahwa pembaca telah memperoleh kemampuan membaca(Samsu Sumadoyo 2013) .Untuk mendapatkan sebuah informasi yang diinginkan melalui kegiatan membaca, maka diperlukan kegiatan membaca yang dapat memahami isi bacaan yang disebut dengan membaca pemahaman(Arwida Endah Zuhari, 2018).Membaca pemahaman menurut Fajri dan Senja adalah suatu kegiatan membaca yang dilakukan pembaca agar tercipta suatu pemahaman terhadap isi yang terkandung dalam bacaan (Intan Nurhidayah, 
2017). Adapun menurut Nursalim di dalam bukunya, membaca pemahaman adalah kegiatan membaca secara mendalam untuk memahami secara lengkap isi buku atau bacaan tertentu.

Permasalahan yang terjadi yang perlu adanya pemecahahan masalah seperti siswa tidak mampu menjawab pertanyaan secara komprehensif dari bahan bacaan, siswa tidak mampu menemukan kata-kata sulit serta artinya di dalam teks bacaan, siswa tidak mampu menentukan gagasan pokok dari setiap paragraph dan siswa tidak mampu menceritakan kembali bahan bacaan menggunakan bahasa sendiri. Berdasarkan gejala yang dikemukakan menurut peneliti perlu kiranya melakukan perubahan pada proses pembelajaran agar kemampuan membaca pemahaman siswa menerapkan metode pembelajaran yang membuat siswa menjadi aktif, sehingga saat pembelajaran siswa mencari dan membangun konsep yang berhubungan dengan materi secara mandiri. Salah satu metode yang mampu meningkatkan kemampuan membaca pemahaman siswa menurut peneliti adalah dengan menerapkan metode pembelajaran overview, key ideas, read, record, recite, review dan reflect (OK5R).

Annisa Mardhiyah (2019) mengemukakan OK5R merupakan metode membaca dengan pendekatan kontruktif karena siswa membangun sendiri pemahamannya melalui langkah-langkah pada metode. Metode ini selaras dengan prinsip membaca pemahaman dimana pemahaman merupakan proses kontuktivis sosial. Adapun menurut Melati dan Putri metode OK5R dapat meningkatkan kemampuan membaca pemahaman bagi siswa yang memiliki minat baca yang rendah. OK5R merupakan singkatan dari langkah- langkah yang terdapat didalamnya, yaitu overview, key ideas, read, record, recite, review dan reflect. Metode ini dirancang sebagai metode belajar untuk membantu dalam memahami bahan bacaan dengan efektif.Menurut Melati dan Putrimetode OK5R dapat meningkatkan kemampuan membaca pemahaman bagi siswa yang memiliki minat baca yang rendah (Annisa Mardhiyah, dkk, Loc. Cit)

Menurut Istarani di dalam bukunya metode pembelajaran adalah cara penyajian materi ajar kepada siswa yang dilakukan oleh guru dalam proses belajar mengajar agar tercapai tujuan yang diinginkan. Bagi guru, metode pembelajaran dijadikan sebagai pedoman dan acuan bertindak yang sistematis dalam pelaksanaan pembelajaran. Bagi siswa, penggunaaan metode pembelajaran dapat mempermudah proses pembelajaran dan mempercepat memahami isi pembelajaran, karena setiap metode pembelajaran dirancanguntuk mempermudah proses pembelajaran. Kemudian diharapkan metode pembelajaran dapat meningkatkan kemampuan membaca pemahaman siswa pada pembelajaran Bahasa Indonesia.

Salah satu metode pembelajaran yang dapat meningkatkan kemampuan membaca pemahaman siswa adalah metode overview, key ideas, read, record, recite, review dan reflect (OK5R). Menurut Paida, metode OK5R merupakan metode membaca dengan pendekatan konstruktif karena siswa membangun sendiri pemahamannya melalui langkah-langkah pada metode. Dengan demikian metode ini selaras dengan prinsip membaca pemahaman dimana pemahaman merupakan proses kontrukvis sosial. Adapun menurut Melati dan Putri, metode ini dapat meningkatkan kemampuan membaca pemahaman bagi siswa yang memiliki minat baca yang rendah. Berdasarkan penjelasan metode overview, key, ideas, read, record, recite, review dan reflect (OK5R) diatas, dapat dipahami bahwa metode ini merupakan salah satu solusi yang dapat digunakan untuk meningkatkan kemampuan membaca pemahaman siswa pada pelajaran Bahasa Indonesia di Sekolah Dasar.

ahasa Indonesia merupakan salah satu mata pelajaran yang penting dalam kehidupan siswa.Siswa dapat memperoleh ilmu pengetahuan, teknologi, seni, dan informasi dengan El-Ibtidaiy: Journal of Primary Education, Vol. 4, No. 2, Oktober 2021, 127 - 143 
berbahasa. Salah satu aspek penting dalam pembelajaran bahasa Indonesia adalah membaca. Membaca merupakan salah satu jenis kemampuan berbahasa yang harus dikuasai siswa. Melalui membacalah siswa akan memperoleh informasi, ilmu pengetahuan dan pengalaman-pengalaman baru. Tujuan akhir dari membaca adalah memahami isi bacaan, itu disebut membaca pemahaman.Akan tetapi pada kenyataan yang ada belum semua siswa dapat mencapai tujuan tersebut.Banyak siswa yang dapat membaca secara lancar semua bacaan tetapi tidak memahami isi bacaan tersebut. Selama ini, pembelajaran bahasa Indonesia juga masih didominasi oleh metode ceramah dan tanya jawab, sehingga siswa kurang dilibatkan dalam proses pembelajaran.

Guru perlu mengubah metode pembelajaran yang mampu meningkatkan kemampuan membaca pemahaman siswa, dan jawabannya ada pada metode overview, key ideas, read, record, recite, review and reflect (OK5R). Menurut Melati dan Putri metode inidapat meningkatkan kemampuan membaca pemahaman bagi siswa yang memiliki minat baca yang rendah.Untuk mengetahui apakahmetode overview, key ideas, read, record, recite, review dan reflect(OK5R) dapat meningkatkan kemampuan membaca pemahaman siswa, maka perlu diperjelas variabel penelitian sebagai bahan yang akan dijadikan untuk penelitian. Untuk lebih jelas dapat dilihat pada gambar skema kerangka berfikir dibawah ini:

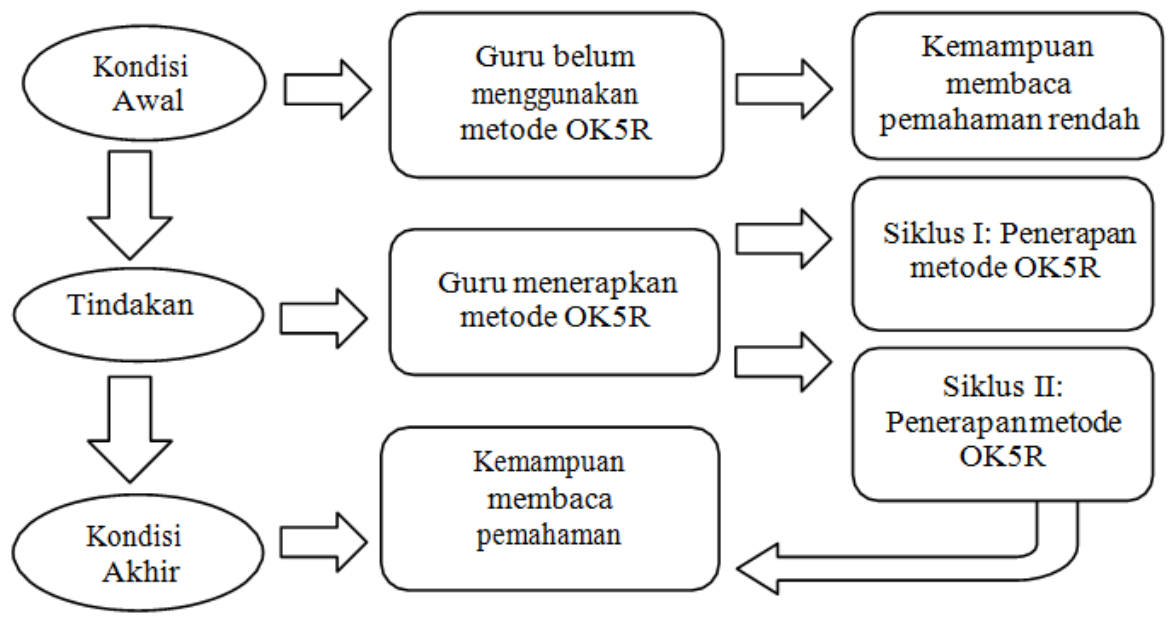

Gambar 1 Skema Kerangka Berfikir

\section{METODOLOGI}

Bentuk penelitian ini adalah penelitian tindakan kelas (PTK), Penelitian tindakan kelas merupakan penelitian yang dilakukan oleh guru di kelasnya masing-masing dengan cara merencanakan, melaksanakan, dan merefleksikan tindakan secara kolaboratif dan partisipatif dengan tujuan memperbaiki kinerjanya sebagai guru, sehingga hasil belajar siswa dapat meningkat. Secara garis besar penelitian tindakan kelas dilaksanakan melalui empat tahapan yaitu perencanaan, pelaksanaan, observasi dan refleksi. Adapun daur siklus penelitian tindakan kelas (PTK) adalah sebagai berikut: 


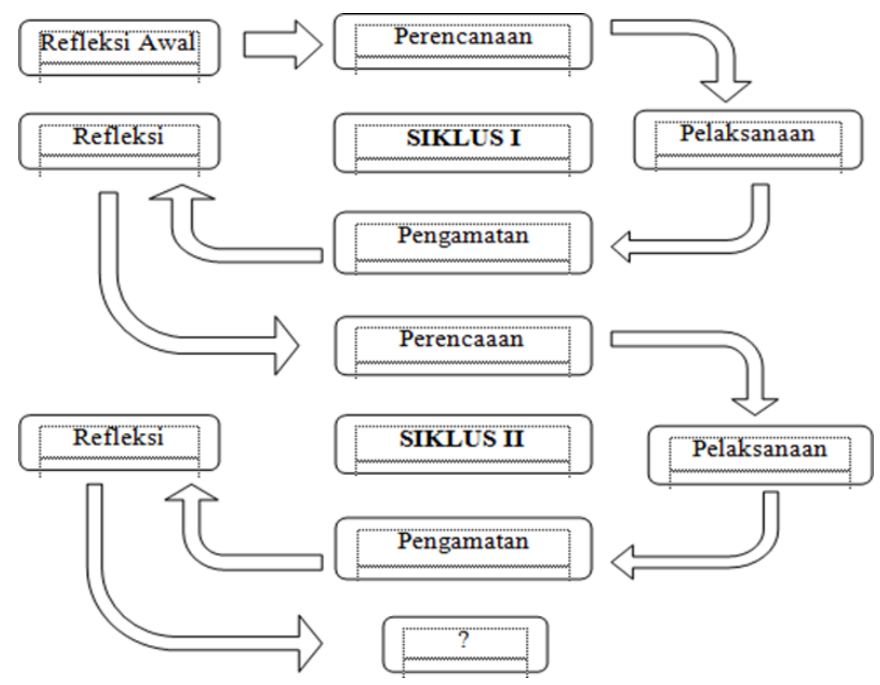

\section{Gambar 2 Siklus Penelitian Tindakan Kelas}

Teknik analisis data dalam penelitian ini adalah teknik analisis deskriptif kualitatif dengan persentase. Analisis deskriptif kualitatif yaitu suatu metode yang bersifat menggambarkan kenyataan atau fakta sesuai dengan data yang diperoleh dengan tujuan untuk mengetahui hasil belajar yang dicapai siswa dan untuk mengetahui respon siswa terhadap kegiatan pembelajaran serta aktivitas siswa selama proses pembelajaran berlangsung(Saprun, 2020:34). Setelah data Aktivitas Guru dan Siswa terkumpul melalui observasi, data tersebut kemudian diolah dengan menggunakan rumus persentase(Anas Sudijono, 2010). Menentukan kriteria penilain terkait aktivitas guru dan aktivitas siswa, maka dilakukan pengelompokkan atas empat kriteria penilaian. Kriteria penilaian tersebut adalah sebagai berikut:

\section{Tabel 1 Interval Kategori Aktivitas Guru dan Siswa}

\begin{tabular}{cc}
\hline Interval (\%) & Kategori \\
\hline $91-100$ & Sangat Tinggi \\
$76-90$ & Tinggi \\
$55-75$ & Cukup Tinggi \\
$0-54$ & Kurang Tinggi \\
\hline
\end{tabular}

Kemampuan siswa dalam membaca pemahaman, maka dapat diturunkan ke dalam rumus (Zainal Aqib, 2009). Sedangkan untuk menentukan ketuntuasan secara Klasikal (Suslawati, 2019). Adapun kriteria penilaian kemampuan membaca pemahaman siswa dilihat dari KKM Sekolah Dasar Negeri 006 Saloyaitu 70 dengan kriteria sebagai berikut:

\section{Tabe 2 Kriteria Ketuntasan Minimal}

\begin{tabular}{cc}
\hline Interval (\%) & Kategori \\
\hline $91-100$ & Sangat Baik \\
$81-90$ & Baik \\
$70-80$ & Cukup Baik \\
$<70$ & Kurang Baik \\
\hline
\end{tabular}




\section{TEMUAN DAN DISKUSI}

Penelitian ini terdiri dari 2 siklus dan setiap siklusnya terdiri dari 2 kali petemuan.Pada setiap siklus terdiri dari tahap perencanaan, tahap tindakan, tahap observasi dan tahap refleksi.

\section{Siklis I}

\section{Perencanaan Tindakan Siklus I}

Tahap perencanaan ini dilakukan untuk mempersiapkan perangkat pembelajaran yang akan dilakukan. Adapun yang akan dipersiapkan adalah menyusun RPP (Rencana Pelaksanaan Pembelajaran) berdasarkan standar kompetensi dan kompetensi dasar dalam menggunakan metode overview, key ideas, read, record, recite, review dan reflect (OK5R). Kemudian mempersiapkan silabus sesuai dengan mata pelajaran yang akan diteliti yaitu mata pelajaran Bahasa Indonesia. Selanjutnya meminta kesediaan guru kelas IVA untuk menjadi observer aktivitas siswa dan teman sejawat untuk menjadi observer aktivitas guru, mempersiapkan materi yang akan disajikan. Selain itu, guru juga mempersiapkan media/alat-alat yang dibutuhkan dalam proses pembelajaran, seperti lembar kerja siswa dan soal ulangan siklus I. Setelah merencanakan, menyusun dan mempersiapkan segala sesuatu yang dibutuhkan dalam penelitian maka dilanjutkan dengan pelaksanaan tindakan.

\section{Pelaksanaan Tindakan Siklus I}

Pertemuan pertama siklus I dilaksanakan pada hari Rabu, 27 Januari 2021 dan pertemuan kedua dilaksanakan pada hari Kamis, 28 Januari 2021.Jadwal penelitian ini sesuai dengan jadwal pembelajaran yang telah ditetapkan di kelas IVA Sekolah Dasar Negeri 006 Salo.Sedangkan waktu yang dibutuhkan pada setiap kali pertemuan adalah 2 × 35 menit.

\section{Observasi Siklus I}

Adapun rekapitulasi aktivitas guru dalam pembelajaran dengan menggunakan metodeoverview, key ideas, read, record, recite, review dan reflect(OK5R), dapat dilihat pada tabel 3.

Berdasarkan tabel IV.12 dapat diketahui bahwa persentase yang diperoleh pada aktivitas guru selama proses pembelajaran dengan menggunakan metode overview, key ideas, read, record, recite, review dan reflect (OK5R) pada pertemuan 1 di siklus I adalah 67,85\% atau tergolong "cukup tinggi" karena $67,85 \%$ berada pada rentang 55-75\%. Sedangkan penerapan metode overview, key ideas, read, record, recite, review dan reflect (OK5R) pada pertemuan 2 di siklus I adalah 75\% atau tergolong "cukup tinggi" karena 75\% berada pada rentang 55-75\%. Secara keseluruhan persentase pada aktivitas guru selama proses pembelajaran dengan menggunakan metode overview, key ideas, read, record, recite, review danreflect (OK5R) pada siklus I (pertemuan 1 dan 2) adalah 71,42\% atau tergolong "cukup tinggi" karena 71,42\% berada pada rentang $55-75 \%$.

Adapun rekapitulasi hasil observasi aktivitas siswa pada siklus I pertemuan pertama dan kedua menggunakan metode overview, key ideas, read, record, recite, review dan reflect (OK5R) pada tema Indahnya Keragaman di Negeriku muatan pelajaran Bahasa Indonesia dapat dilihat pada tabel 4 . 
Tabel 3

Rekapitulasi Hasil Observasi Aktivitas Guru dengan Penerapan Metode OK5R Pada Siklus I (Pertemuan 1 dan 2)

\begin{tabular}{|c|c|c|c|}
\hline \multirow{2}{*}{ Aspek yang diamati } & \multicolumn{3}{|c|}{ Jumlah Skor } \\
\hline & Pert.1 & Pert.2 & Siklus 1 \\
\hline $\begin{array}{l}\text { Guru memerintahkan siswa untuk membaca judul, } \\
\text { menemukan kata-kata sulit yang terdapat pada } \\
\text { bacaan dan artinya untuk memperoleh gambaran } \\
\text { secara } \\
\text { umum. }\end{array}$ & 3 & 3 & 3 \\
\hline Guru memerintahkan siswa memilah & & & \\
\hline $\begin{array}{l}\text { antara gagasan pokok dari bahan-bahan penunjang. } \\
\text { Guru mengarahkan siswa untuk membaca suatu }\end{array}$ & 3 & 4 & 3,5 \\
\hline paragraf terlebih dahulu lalu guru & 3 & 3 & 3 \\
\hline $\begin{array}{l}\text { Guru memerintahkan siswa untuk } \\
\text { mencatat hasil pemahaman dari teks cerita }\end{array}$ & 3 & 3 & 3 \\
\hline $\begin{array}{l}\text { yangdibacadenganmenuliskanpadabuku. } \\
\text { Guru membimbing siswa mengungkapkan }\end{array}$ & & & \\
\hline pemahamannya dengan & 3 & 3 & 3 \\
\hline $\begin{array}{l}\text { kata-kata sendiri. } \\
\text { Guru memerintahkan siswa } \\
\text { mengungkapkan kembali seluruh gagasan } \\
\text { pokok dan penunjang. }\end{array}$ & 2 & 2 & 2 \\
\hline $\begin{array}{l}\text { Guru memberikan arahan kepada siswa untuk } \\
\text { merefleksi pengetahuannya dengan mendiskusikan } \\
\text { hasil rangkumanyangtelah ditulisnya bersama teman } \\
\text { sebangku dan menambahkan catatan pada } \\
\text { rangkumannya } \\
\text { berdasarkan hasil diskusi. }\end{array}$ & 2 & 3 & 2,5 \\
\hline Jumlah & 19 & 21 & 20 \\
\hline Persentase & $67,85 \%$ & $75 \%$ & $71,42 \%$ \\
\hline Kategori & $\begin{array}{l}\text { Cukup } \\
\text { Tinggi }\end{array}$ & $\begin{array}{l}\text { Cukup } \\
\text { Tinggi }\end{array}$ & $\begin{array}{l}\text { Cukup } \\
\text { Tinggi }\end{array}$ \\
\hline
\end{tabular}




\section{Tabel 4}

\section{Rekapitulasi Hasil Observasi Aktivitas Siswa dengan Penerapan Metode OK5R Siklus I (Pertemuan 1 dan 2)}

\begin{tabular}{|c|c|c|c|c|c|c|c|}
\hline \multirow{3}{*}{ Aktivitas Yang Diamati } & \multicolumn{5}{|c|}{ Siklus 1} & \multirow{2}{*}{\multicolumn{2}{|c|}{$\begin{array}{l}\text { Total } \\
\text { Rata-rata }\end{array}$}} \\
\hline & \multirow{2}{*}{$\begin{array}{r}\text { Pert } 1 \\
\text { Skor }\end{array}$} & \multirow[b]{2}{*}{$\%$} & \multicolumn{3}{|c|}{ Pert II } & & \\
\hline & & & & Skor & $\%$ & Skor & $\%$ \\
\hline $\begin{array}{l}\text { Siswa membaca judul, menemukan kata- } \\
\text { kata sulit yang terdapat pada bacaan dan } \\
\text { artinya } \\
\text { untuk memperoleh gambaran secara } \\
\text { umum. }\end{array}$ & 58 & $69,04 \%$ & & 64 & $76,19 \%$ & 61 & $72,61 \%$ \\
\hline $\begin{array}{l}\text { Siswa memilah antara gagasan pokok } \\
\text { dari bahan-bahan } \\
\text { penunjang. }\end{array}$ & 54 & $64,28 \%$ & & 62 & $73,80 \%$ & 58 & $69,04 \%$ \\
\hline $\begin{array}{l}\text { Siswa membaca suatu paragraf terlebih } \\
\text { dahulu dan menjawab } \\
\text { pertanyaan guru. }\end{array}$ & 52 & $61,90 \%$ & & 58 & $69,04 \%$ & 55 & $65,47 \%$ \\
\hline $\begin{array}{l}\text { Siswa mencatat hasil pemahaman } \\
\text { terhadap teks cerita yang dibaca dengan } \\
\text { menuliskan pada buku. }\end{array}$ & 54 & $64,28 \%$ & & 57 & $67,85 \%$ & 55,5 & $66,06 \%$ \\
\hline $\begin{array}{l}\text { Siswa mengungkapkan } \\
\text { pemahamannya secara lisan dengan } \\
\text { menggunakan kata-kata } \\
\text { sendiri, untuk menghindari kelupaan. }\end{array}$ & 50 & $59,52 \%$ & 55 & & $65,47 \%$ & 52,5 & $62,49 \%$ \\
\hline $\begin{array}{l}\text { Siswa mengungkapkan kembali seluruh } \\
\text { gagasan pokok dan bahan } \\
\text { penunjang. }\end{array}$ & 60 & $71,42 \%$ & & 65 & $77,38 \%$ & 62,5 & $74,4 \%$ \\
\hline $\begin{array}{l}\text { Siswa mendiskusikan hasil rangkuman } \\
\text { yang telah ditulisnya bersama teman } \\
\text { sebangku dan menambahkan catatan } \\
\text { pada rangkumannya berdasarkan hasil } \\
\text { diskusi. }\end{array}$ & 56 & $66,66 \%$ & & 63 & $75 \%$ & 59,5 & $70,83 \%$ \\
\hline Jumlah/Persentase & 384 & $65,30 \%$ & & 424 & $72,10 \%$ & 404 & $68,07 \%$ \\
\hline
\end{tabular}

Berdasarkan tabel di atas, diketahui bahwa persentase yang diperoleh aktivitas siswa dengan penerapan metode overview, key ideas, read, record, recite, review dan reflect (OK5R) pada pertemuan I di siklus 1 adalah 65,30\% atau tegolong "cukup tinggi", karena 65,30\% berada pada rentang $55-75 \%$. Sedangkan aktivitas siswa dengan penerapan metode overview, key ideas, read, record, recite, review dan reflect (OK5R) pada pertemuan 2 siklus I adalah 72,10\% atau tegolong "cukup tinggi", karena 72,10\% berada pada rentang 55-75\%. Secara keseluruhan aktivitas siswa dengan penerapan metode overview, key ideas, read, record, recite, review dan 
reflect (OK5R) pada siklus I adalah 68,07\% atau tergolong “cukup tinggi”, karena 68,07\% berada pada rentang $55-75 \%$.

Berdasarkan hasil observasi di atas diketahui bahwa: 1) Siswa membaca judul, menemukan kata sulit yang terdapat pada bacaan dan artinya untuk memperoleh gambaran secara umum, persentase kegiatan ini adalah 72,61\% dengan kategori "cukup tinggi" karena 72,61\% berada pada rentang $55-75 \%$, 2) Siswa memilah antara gagasan pokok dari bahan-bahan penunjang, persentase kegiatan ini adalah 69,04\% dengan kategori "cukup tinggi" karena 69,04\% berada pada rentang $55-75 \%$, 3) Siswa membaca suatu paragraf terlebih dahulu dan menjawab pertanyaan guru, persentase kegiatan ini adalah 65,47\% dengan kategori "cukup tinggi" karena 65,47\% berada pada rentang $55-75 \%$, 4) Siswa mencatat hasil pemahaman terhadap teks cerita yang dibaca dengan menuliskan pada buku, persentase kegiatan ini adalah 66,06\% dengan kategori "cukup tinggi" karena $66,06 \%$ berada pada rentang $55-75 \%, 5)$.

Siswa mengungkapkan pemahamannya secara lisan dengan menggunakan kata-kata sendiri, untuk menghindari kelupaan, persentase kegiatan ini adalah 62,49\% dengan kategori "cukup tinggi" karena 62,49\% berada pada rentang 55-75\%, 6) Siswa mengungkapkan kembali seluruh gagasan pokok dan bahan penunjang, persentase kegiatan ini adalah 74,4\% dengan kategori "cukup tinggi" karena $74,4 \%$ berada pada rentang 55-75\%, 7) Siswa merefleksi pengetahuannya dengan mendiskusikan hasil rangkuman yang telah ditulisnya bersama teman sebangku dan menambahkan catatan pada rangkumannya berdasarkan hasil diskusi, persentase kegiatan ini adalah 70,83\% dengan kategori "cukup tinggi" karena 70,83\% berada pada rentang 55-75\%. Hasil Tes Kemampuan Membaca Pemahaman Siswa Siklus 1

Tes terhadap kemampuan membaca pemahaman siswa dilakukan diluar jam pembelajaran yaitu pada saat setelah dua kali pertemuan selesai. Adapun jumlah siswa yang mengikuti tes yaitu 21 orang. Sedangkan untuk kriteria kemampuan membaca pemahaman yaitu jika nilai siswa mencapai 91-100 berada pada kategori "sangat baik", jika nilai 81-90 berada pada ketegori "baik", jika nilai 70-80 berada pada kategori "cukup baik", dan jika nilai $<70$ berada pada kategori "kurang baik". Adapun hasil tes kemampuan membaca pemahaman siswa pada siklus I dapat dilihat pada tabel 5.

\section{Refleksi Siklus I}

Berdasarkan hasil tes penelitian pada siklus I, maka dapat disimpulkan bahwa kemampuan membaca pemahaman siswa hanya mencapai rata-rata 72,28 atau tergolong "cukup baik". Dari 21 siswa, hanya 14 orang siswa yang "tuntas" sedangkan 7 orang siswa "tidak tuntas". Adapun kemampuan membaca pemahaman siswa secara klasikal 66,66\%. Dengan demikian kemampuan membaca pemahaman siswa pada siklus I belum bisa dikatakan baik, karena dikatakan "baik" apabila mencapai nilai 81-90 atau "sangat baik" apabila mencapai nilai 91-100. Selanjutnya peneliti melakukan refleksi yang berguna untuk memperbaiki kekurangan-kekurangan yang terjadi pada siklus 1 agar siklus selanjutnya tidak terulang kembali kelemahan-kelemahan atau kesalahan tersebut.

\section{Siklus II}

\section{Perencanaan Tindakan Siklus II}

Siklus ini merupakan kelanjutan dari siklus I. Setelah mengetahui hasil penelitian dari siklus I, langkah selanjutnya adalah menyusun hal-hal yang diperlukan untuk melaksanakan siklus II. Adapun yang akan dipersiapkan adalah menyusun RPP (Rencana Pelaksanaan Pembelajaran) berdasarkan standar kompetensi dan kompetensi dasar dalam menggunakan metode overview, 
key ideas, read, record, recite, review dan reflect (OK5R). Selanjutnya meminta kesediaan guru kelas IVA untuk menjadi observer aktivitas siswa dan teman sejawat untuk menjadi observer aktivitas guru, dan mempersiapkan materi yang akan disajikan. Selain itu, guru juga mempersiapkan media/alat-alatyang dibutuhkan dalam proses pembelajaran, seperti lembar kerja siswa dan soal ulangan siklus II. Setelah merencanakan, menyusun dan mempersiapkan segala sesuatu yang dibutuhkan dalam penelitian maka dilanjutkan dengan pelaksanaan tindakan.

Tabel 5

Hasil Kemampuan Membaca Pemahaman Siswa Kelas IVA Sekolah Dasar Negeri 006 Salo Pada Siklus I

\begin{tabular}{|c|c|c|c|c|c|c|}
\hline \multirow{2}{*}{$\begin{array}{l}\text { Kode } \\
\text { Siswa }\end{array}$} & \multicolumn{4}{|c|}{ Indikator } & \multirow{2}{*}{ Jumlah } & \multirow{2}{*}{ Keterangan } \\
\hline & 1 & 2 & 3 & 4 & & \\
\hline Siswa 001 & 20 & 20 & 15 & 18 & 73 & Cukup \\
\hline Siswa 002 & 16 & 20 & 15 & 24 & 75 & Cukup \\
\hline Siswa 003 & 20 & 20 & 24 & 18 & 82 & Baik \\
\hline Siswa 004 & 20 & 16 & 30 & 18 & 84 & Baik \\
\hline Siswa 005 & 20 & 20 & 6 & 6 & 52 & Kurang \\
\hline Siswa 006 & 20 & 16 & 15 & 24 & 75 & Cukup \\
\hline Siswa 007 & 20 & 20 & 6 & 6 & 52 & Kurang \\
\hline Siswa 008 & 16 & 20 & 15 & 30 & 81 & Cukup \\
\hline Siswa 009 & 20 & 16 & 30 & 6 & 72 & Cukup \\
\hline Siswa 010 & 20 & 20 & 30 & 12 & 82 & Baik \\
\hline Siswa 011 & 20 & 20 & 15 & 18 & 73 & Cukup \\
\hline Siswa 012 & 16 & 20 & 6 & 18 & 60 & Kurang \\
\hline Siswa 013 & 20 & 16 & 6 & 18 & 60 & Kurang \\
\hline Siswa 014 & 16 & 16 & 30 & 24 & 86 & Baik \\
\hline Siswa 015 & 20 & 16 & 30 & 18 & 84 & Baik \\
\hline Siswa 016 & 16 & 16 & 24 & 6 & 62 & Kurang \\
\hline Siswa 017 & 20 & 16 & 6 & 18 & 60 & Kurang \\
\hline Siswa 018 & 20 & 20 & 15 & 30 & 85 & Baik \\
\hline Siswa 019 & 20 & 20 & 15 & 18 & 73 & Cukup \\
\hline Siswa 020 & 10 & 10 & 15 & 30 & 65 & Kurang \\
\hline Siswa 021 & 10 & 20 & 30 & 12 & 72 & Cukup \\
\hline Junlah & 380 & 370 & 378 & 372 & 1508 & \\
\hline Rata-Rata & 72,38 & 70,47 & 72,00 & 70,85 & 72,28 & Cukup \\
\hline
\end{tabular}

Pertemuan pertama siklus II dilaksanakan pada hari Senin, 1 Februari 2021 dan pertemuan kedua dilaksanakan pada hari Selasa, 2 Februari 2021.Jadwal penelitian ini sesuai dengan jadwal pembelajaran yang telah ditetapkan di kelas IVA Sekolah Dasar Negeri 006 Salo.Sedangkan waktu yang dibutuhkan pada setiap kali pertemuan adalah 2 x 35 menit.

\section{Observasi Siklus II}

Adapun rekapitulasi aktivitas guru dalam pembelajaran dengan menggunakan metode pembelajaran pembelajaran overview, key ideas, read, record, recite, review dan reflect (OK5R) pada siklus II, dapat dilihat pada tabel berikut: 
Tabel 6

Rekapitulasi Hasil Observasi Aktivitas Guru dengan Penerapkan Metode OK5R Pada Siklus II (Pertemuan 1 dan 2)

\begin{tabular}{|c|c|c|c|}
\hline \multirow[t]{2}{*}{ Aspek yang diamati } & \multicolumn{3}{|c|}{ Jumlah Skor } \\
\hline & Pert.1 & Pert.2 & Siklus \\
\hline $\begin{array}{l}\text { Guru memerintahkan siswa untuk membaca } \\
\text { judul, menemukan kata-kata sulit yang terdapat } \\
\text { pada bacaan dan } \\
\text { artinya untuk memperoleh gambaran secara } \\
\text { umum. }\end{array}$ & 3 & 4 & 3,5 \\
\hline $\begin{array}{l}\text { Guru memerintahkan siswa memilah } \\
\text { antara gagasan pokok dari bahan-bahan } \\
\text { penunjang. }\end{array}$ & 4 & 4 & 4 \\
\hline $\begin{array}{l}\text { Guru mengarahkan siswa untuk membaca suatu } \\
\text { paragraf terlebih dahulu lalu guru mengajukan } \\
\text { pertanyaan }\end{array}$ & 4 & 3 & 3,5 \\
\hline $\begin{array}{l}\text { kepada siswa. } \\
\text { Guru memerintahkan siswa untuk mencatat } \\
\text { hasil pemahaman dari teks cerita yang dibaca } \\
\text { dengan menuliskan } \\
\text { pada buku. }\end{array}$ & 3 & 4 & 3,5 \\
\hline $\begin{array}{l}\text { Guru membimbing siswa mengungkapkan } \\
\text { pemahamannya dengan menggunakan kata-kata } \\
\text { sendiri. }\end{array}$ & 3 & 3 & 3 \\
\hline $\begin{array}{l}\text { Guru memerintahkan siswa mengungkapkan } \\
\text { kembali seluruh gagasan pokok dan penunjang. }\end{array}$ & 3 & 4 & 3,5 \\
\hline $\begin{array}{l}\text { Guru memberikan arahan kepada siswa untuk } \\
\text { merefleksi pengetahuannya dengan } \\
\text { mendiskusikan hasil rangkuman yang telah } \\
\text { ditulisnya bersama teman sebangku dan } \\
\text { menambahkan catatan pada rangkumannya } \\
\text { berdasarkan hasil diskusi. }\end{array}$ & 4 & 4 & 4 \\
\hline Jumlah & 24 & 26 & 25 \\
\hline Persentase & $85,71 \%$ & $92,85 \%$ & $89,28 \%$ \\
\hline Kategori & Tinggi & $\begin{array}{l}\text { Sangat } \\
\text { Tinggi }\end{array}$ & Tinggi \\
\hline
\end{tabular}

Berdasarkan tabel di atas dapat diketahui bahwa persentase yang diperoleh pada aktivitas guru selama proses pembelajaran dengan menggunakan metode overview, key ideas, read, record, recite, review dan reflect (OK5R) pada pertemuan 1 di siklus II adalah 85,71\% atau tegolong "tinggi" karena 85,71\% berada pada rentang 76-90\%. Sedangkan penerapan metode overview, key ideas, read, record, recite, review dan reflect (OK5R) pada pertemuan 2 di siklus II adalah $92,85 \%$ atau tegolong "sangat tinggi" karena 92,85\% berada pada rentang $91-100 \%$. Secara keseluruhan aktivitas guru dengan penerapan metode overview, key ideas, read, record, recite, review dan reflect (OK5R) pada siklus II adalah 89,28\% atau tergolong "tinggi" karena 89,28\% berada pada rentang $76-90 \%$.

Adapun rekapitulasi hasil observasi aktivitas siswa pada siklus II pertemuan pertama dan kedua menggunakan metode overview, key ideas, read, record, recite, review dan reflect (OK5R) E1-Ibtidaiy: Journal of Primary Education, Vol. 4, No. 2, Oktober 2021, 127 - 143 
pada tema Indahnya Keragaman di Negeriku muatan pelajaran Bahasa Indonesia dapat dilihat pada tabel berikut:

Tabel 7

Rekapitulasi Hasil Observasi Aktivitas Siswa Dengan Penerapan Metode OK5R Siklus II (Pertemuan 1 dan 2)

\begin{tabular}{|c|c|c|c|c|c|c|}
\hline \multirow{3}{*}{ Aktivitas Yang Diamati } & \multicolumn{4}{|c|}{ Siklus 1I } & \multirow{2}{*}{\multicolumn{2}{|c|}{$\begin{array}{l}\text { Total } \\
\text { Rata-rata }\end{array}$}} \\
\hline & \multicolumn{2}{|c|}{ Pert 1} & \multicolumn{2}{|c|}{ Pert II } & & \\
\hline & Skor & $\%$ & Skor & $\%$ & Skor & $\%$ \\
\hline 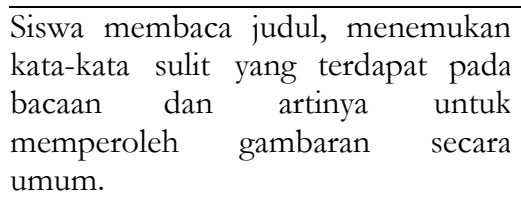 & 70 & $83,33 \%$ & 76 & $90,47 \%$ & 73 & $86,9 \%$ \\
\hline $\begin{array}{l}\text { Siswa memilah antara gagasan pokok } \\
\text { dari } \quad \text { bahan-bahan penunjang. }\end{array}$ & 67 & $79,76 \%$ & 74 & $88,09 \%$ & 70,5 & $83,92 \%$ \\
\hline $\begin{array}{l}\text { Siswamembaca suatu paragraf terlebih } \\
\text { dahulu dan menjawab pertanyaan } \\
\text { guru. }\end{array}$ & 65 & $77,38 \%$ & 70 & $83,33 \%$ & 67,5 & $80,35 \%$ \\
\hline $\begin{array}{l}\text { Siswa mencatat hasil pemahaman } \\
\text { terhadap teks cerita yang dibaca } \\
\text { dengan menuliskan pada buku. } \\
\text { Siswa mengungkapkan } \\
\text { pemahamannya secara lisan dengan } \\
\text { menggunakan kata-kata sendiri, } \\
\text { untuk menghindari kelupaan. }\end{array}$ & 63 & $71,42 \%$ & 68 & $85,71 \%$ & 67.5 & $76,18 \%$ \\
\hline $\begin{array}{l}\text { Siswa mengungkapkan kembali } \\
\text { seluruh gagasan pokok dan bahan } \\
\text { penunjang. }\end{array}$ & 72 & $85,71 \%$ & 78 & $92,85 \%$ & 75 & $89,28 \%$ \\
\hline 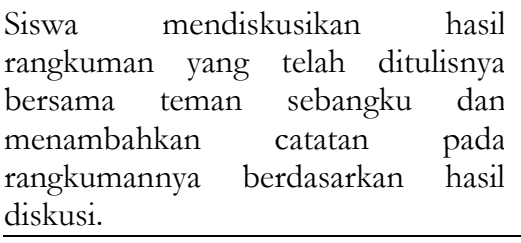 & 68 & $80,95 \%$ & 75 & $89,28 \%$ & 71,5 & $85,11 \%$ \\
\hline Jumlah/Persentase & 465 & $79,08 \%$ & 513 & $87,24 \%$ & 489 & $83,15 \%$ \\
\hline Kategori & & Tinggi & & & & \\
\hline
\end{tabular}

Ketahui bahwa persentase yang diperoleh aktivitas siswa dengan penerapan metode overview, key ideas, read, record, recite, review dan reflect (OK5R) pada pertemuan 1 di siklus II adalah 79,08\% atau tegolong "tinggi", karena 79,08\% berada pada rentang $76-90 \%$. Sedangkan aktivitas siswa dengan penerapan metode overview, key ideas, read, record, recite, review dan reflect (OK5R) pada pertemuan 2 siklus II adalah 87,24\% atau tegolong "tinggi", karena 87,24\% berada pada rentang 76-90\%. Secara keseluruhan aktivitas siswa dengan penerapan metode overview, key ideas, read, record, recite, review danreflect (OK5R) pada siklus II adalah 83,15\% atau tergolong "tinggi", karena 83,15\% berada pada rentang 76-90\%. Berdasarkan hasil observasi di atas diketahui bahwa: 1) Siswa membaca judul, menemukan kata-kata sulit yang terdapat pada bacaan dan artinya untuk memperoleh gambaran secara umum, persentase kegiatan ini adalah $86,9 \%$ dengan kategori "tinggi" karena 86,9\% berada pada rentang 76-90\%, 2) Siswa memilah antara gagasan pokok dari bahan- bahan penunjang, persentase kegiatan ini adalah 83,92\%

El-Ibtidaiy: Journal of Primary Education, Vol. 4, No. 2, Oktober 2021, 127 - 143 
dengan kategori "tinggi" karena 83,92\% berada pada rentang 76-90\%, 3) Siswa membaca suatu paragraf terlebih dahulu dan menjawab pertanyaan guru, persentase kegiatan ini adalah $80,35 \%$ dengan kategori "tinggi" karena 80,35\% berada pada rentang 76-90\%, 4) Siswa mencatat hasil pemahaman terhadap teks cerita yang dibaca dengan menuliskan pada buku, persentase kegiatan ini adalah 80,35\% dengan kategori "tinggi" karena 80,35\% berada pada rentang 76-90\%,5) Siswa mengungkapkan pemahamannya secara lisan dengan menggunakan kata-kata sendiri, untuk menghindari kelupaan, persentase kegiatan ini adalah 76,18\% dengan kategori "tinggi" karena $76,18 \%$ berada pada rentang $76,90 \%$, 6) Siswa mengungkapkan kembali seluruh gagasan pokok dan bahan penunjang, persentase kegiatan ini adalah 89,28\% dengan kategori "tinggi" karena $89,28 \%$ berada pada rentang $76-90 \%$, 7) Siswa mendiskusikan hasil rangkuman yang telah ditulisnya bersama teman sebangku dan menambahkan catatan pada rangkumannya berdasarkan hasil diskusi, persentase kegiatan ini adalah 85,11\% dengan kategori "tinggi" karena 85,11\% berada pada rentang $76-90 \%$.

\section{Hasil Tes Kemampuan Membaca Pemahaman Siklus II}

Adapun hasil tes kemampuan membaca pemahaman siswa dengan menggunakan metode overview, key ideas, read, record, recite, review dan reflect (OK5R) pada siklus II. dapat dilihat pada tabel berikut:

Tabel 8 Hasil Kemampuan Membaca Pemahaman Siswa Kelas IVA Sekolah Dasar Negeri 006 Salo Pada Siklus II

\begin{tabular}{|c|c|c|c|c|c|c|}
\hline \multirow{2}{*}{$\begin{array}{l}\text { Kode } \\
\text { Siswa }\end{array}$} & \multicolumn{4}{|c|}{ Indikator } & \multirow{2}{*}{ Jumlah } & \multirow{2}{*}{ Keterangan } \\
\hline & 1 & 2 & 3 & 4 & & \\
\hline Siswa 001 & 20 & 20 & 15 & 30 & 85 & Baik \\
\hline Siswa 002 & 20 & 20 & 30 & 18 & 88 & Baik \\
\hline Siswa 003 & 20 & 20 & 15 & 30 & 85 & Baik \\
\hline Siswa 004 & 20 & 20 & 30 & 30 & 100 & Sangat Baik \\
\hline Siswa 005 & 20 & 16 & 6 & 18 & 60 & Kurang \\
\hline Siswa 006 & 20 & 20 & 30 & 12 & 82 & Baik \\
\hline Siswa 007 & 16 & 16 & 15 & 30 & 81 & Baik \\
\hline Siswa 008 & 16 & 20 & 15 & 12 & 63 & Kurang \\
\hline Siswa 009 & 20 & 20 & 30 & 18 & 88 & Baik \\
\hline Siswa 010 & 20 & 20 & 24 & 18 & 82 & Baik \\
\hline Siswa 011 & 20 & 20 & 24 & 12 & 76 & Cukup \\
\hline Siswa 012 & 20 & 16 & 6 & 18 & 60 & Kurang \\
\hline Siswa 013 & 20 & 20 & 24 & 6 & 70 & Cukup \\
\hline Siswa 014 & 20 & 20 & 30 & 24 & 94 & Sangat Baik \\
\hline Siswa 015 & 20 & 20 & 24 & 30 & 94 & Sangat Baik \\
\hline Siswa 016 & 20 & 20 & 15 & 18 & 73 & Cukup \\
\hline Siswa 017 & 20 & 16 & 15 & 24 & 75 & Cukup \\
\hline Siswa 018 & 16 & 20 & 24 & 30 & 90 & Baik \\
\hline Siswa 019 & 20 & 20 & 24 & 24 & 88 & Baik \\
\hline Siswa 020 & 20 & 20 & 30 & 18 & 88 & Baik \\
\hline Siswa 021 & 16 & 20 & 24 & 24 & 84 & Baik \\
\hline Junlah & 404 & 404 & 450 & 444 & 1706 & \\
\hline Rata-Rata & 76,95 & 76,95 & 85,71 & 84,57 & 81,23 & Baik \\
\hline
\end{tabular}

El-Ibtidaiy: Journal of Primary Education, Vol. 4, No. 2, Oktober 2021, 127 - 143 


\section{Refleksi Siklus II}

Setelah melakukan tindakan dan diamati oleh observer selanjutnya peneliti melakukan refleksi untuk merenungkan kesalahan-kesalahan yang terjadi pada siklus II. Pada siklus II ini proses pembelajaran sudah berjalan baik. Hasil tes kemampuan membaca pemahaman yang diperoleh siswapun menunjukkan peningkatan. Namun ada beberapa kelemahan-kelemahan, diantaranya: Guru kurang mengawasi siswa ketika sedang mengerjakan lembar kerja siswa melalui penerapan metode overview, key ideas, read, record, recite, review dan reflect (OK5R).

Sebagaimana diketahui pada siklus II dimana rata-rata nilai yang diperoleh 81,23 sudah diatas KKM yang telah ditetapkan yaitu 70, sedangkan secara klasikal juga sudah tergolong "baik" dengan persentase $85,71 \%$ dan berada pada rentang 81-90\%, artinya kemampuan membaca pemahaman sudah melewati indikator keberhasilan yang merujuk pada KKM yang telah ditetapkan sekolah. Untuk itu, peneliti sekaligus guru tidak perlu melakukan siklus berikutnya, karena hasil kemampuan membaca pemahaman telah meningkat.

Perbandingan kemampuan membaca pemahaman siswa dari sebelum tindakan, siklus I , dan siklus II secara jelas dapat dilihat pada tabel berikut:

\section{Tabel 9}

\begin{tabular}{cccc}
\multicolumn{4}{c}{$\begin{array}{c}\text { Rekapitulasi Persentase Hasil Tes Kemampuan Membaca Pemahaman } \\
\text { Secara Klasikal Dari Sebelum Tindakan, Siklus I, dan Siklus II }\end{array}$} \\
\hline \multirow{2}{*}{ Tes } & $\begin{array}{c}\text { Jumlah } \\
\text { Siswa }\end{array}$ & $\begin{array}{c}\text { Jumlah Siswa } \\
\text { yang Tuntas }\end{array}$ & $\begin{array}{c}\text { Jumlah Siswa yang } \\
\text { Tidak Tuntas }\end{array}$ \\
\hline Sebelum Tindakan & 21 & $9(42,85 \%)$ & $12(57,14 \%)$ \\
Siklus I & 21 & $14(66,66 \%)$ & $7(33,33 \%)$ \\
Siklus II & 21 & $18(85,71 \%)$ & $3(14,28 \%)$ \\
\hline
\end{tabular}

Berdasarkan tabel IV.28, pada sebelum tindakan siswa yang tuntas secara klasikal adalah 9 orang siswa atau 42,85\%, sedangkan siswa yang tidak tuntas adalah 12 orang siswa atau 57,14\%. Pada siklus I siswa yang tuntas secara klasikal meningkat menjadi 14 orang siswa atau $66,66 \%$, sedangkan siswa yang tidak tuntas adalah 7 orang siswa atau 33,33\%, dan pada siklus II siswa yang tuntas secara klasikal adalah 18orang siswa atau 85,71\%, sedangkan siswa yang tidak tuntas adalah 3 orang siswa atau 14,28\%. Untuk lebih jelasnya dapat dilihat pada grafik gambar 3 .

Tabel 10

Rekapitulasi Rata-Rata Nilai Hasil Belajar Siswa dari Sebelum Tindakan Siklus I dan Siklus II

\begin{tabular}{ccc}
\hline Tes & Jumlah Siswa & Rata-Rata Nilai \\
\hline Sebelum Tindakan & 21 & 58,42 \\
Siklus I & 21 & 72,28 \\
Siklus II & 21 & 81,23 \\
\hline
\end{tabular}

Ssebelum tindakan rata-rata nilai tes kemampuan membaca pemahaman siswa 58,42, sedangkan pada siklus I rata-rata nilai tes kemampuan membaca pemahaman siswa 72.28 , dan pada siklus II rata-rata nilai tes kemampuan membaca pemahaman siswa 81,23. perbandingan rata-rata nilai tes kemampuan membaca pemahaman siswa dari sebelum tindakan, siklus I, dan siklus II juga dapat dilihat pada grafik pada gambar 4. 

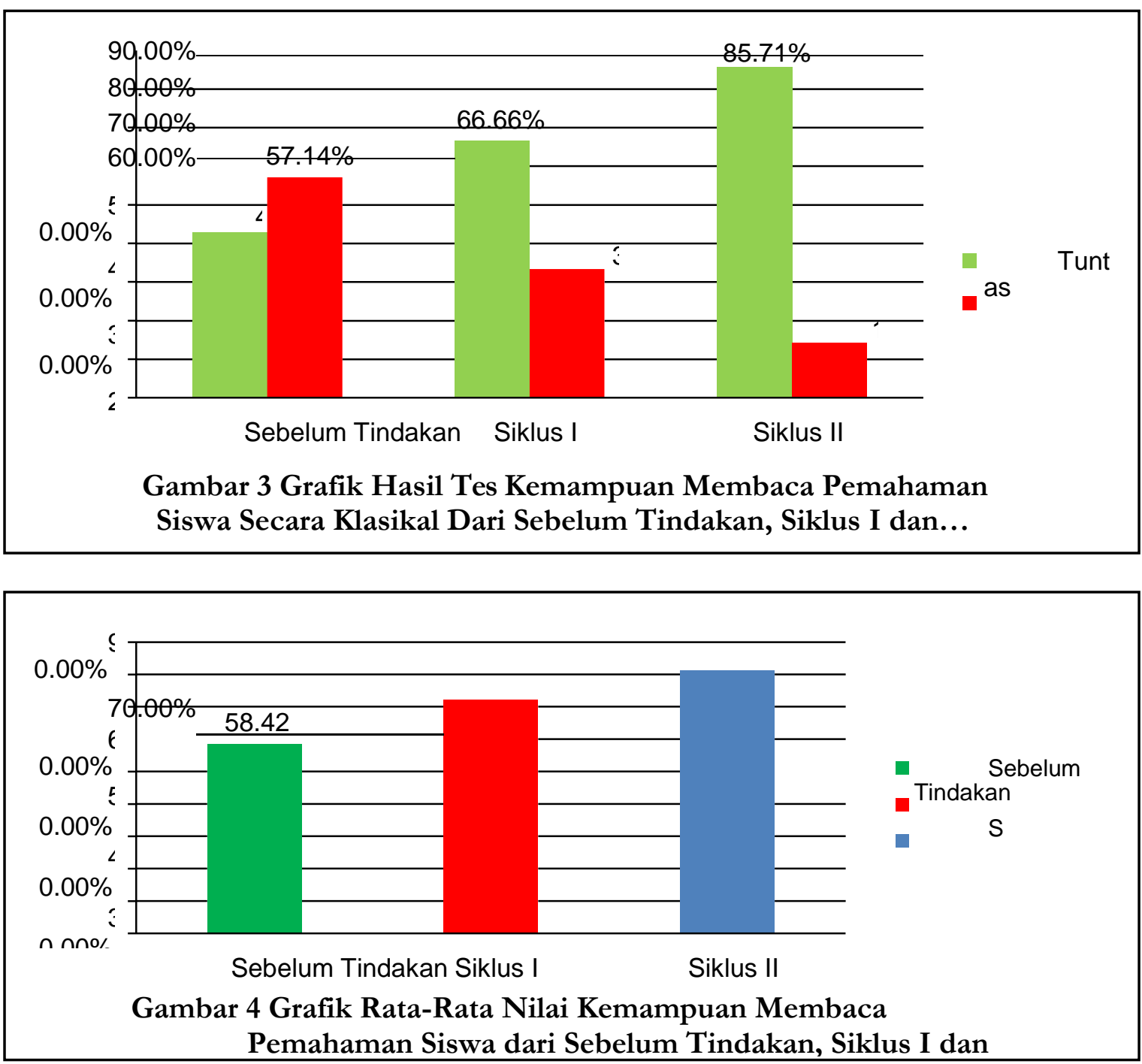

Berdasarkan gambar 4, pada sebelum tindakan rata-rata nilai kemampuan membaca pemahaman siswa 58,42, sedangkan pada siklus I rata-rata nilai kemampuan membaca pemahaman siswa meningkat menjadi 72,28 , dan pada siklus II rata-rata nilai kemampuan membaca pemahaman siswa meningkat lagi menjadi 81,23 . Setelah melihat rekapitulasi persentase hasil kemampuan membaca pemahaman siswa secara klasikal dan rata-rata nilai kemampuan membaca pemahaman siswa dari sebelum tindakan, siklus I, dan siklus II, dapat diketahui bahwa persentase pada siklus II telah mencapai 85,71\%. Dan rata-rata nilai kemampuan membaca pemahaman siswa juga mengalami peningkatan dan sudah melebihi KKMyang telah ditetapkan dalam penelitian ini yaitu 70. Untuk itu peneliti sekaligus guru tidak perlu melakukan siklus berikutnya, karena kemampuan membaca pemahaman siswa pada mata pelajaran Bahasa Indonesia di kelas IVA Sekolah Dasar Negeri 006 Salo Kecamatan Salo Kabupaten Kampar telah meningkat. 


\section{KESIMPULAN}

Berdasarkan hasil penelitian dan analisis data terbukti bahwa melalui penerapan metode overview, key ideas, read, record, recite, review dan reflect (OK5R) dapat meningkatkan kemampuan membaca pemahaman siswa. Hal ini dapat dilihat hasil tes kemampuan membaca pemahaman sebelum tindakan hanya mencapai rata-rata 58,42 dengan ketuntasan klasikal 42,85\% atau tergolong "kurang baik". Setelah menerapkanmetode overview, key ideas, read, record, recite, review dan reflect (OK5R) pada siklus I hasil kemampuan membaca pemahaman siswa meningkat dengan rata- rata 72,28 dengan ketuntasan klasikal 66,66\% atau tergolong "cukup baik". Pada siklus II hasil kemampuan membaca pemahaman siswa meningkat dengan rata-rata 81,23 dengan ketuntasan klasikal 85,71\% atau tergolong "baik". Dengan demikian dapat diambil kesimpulan bahwa kemampuan membaca pemahaman siswa pada tema Indahnya Keragaman di Negeriku muatan pelajaran Bahasa Indonesia kelas IVA Sekolah Dasar Negeri 006 Salo dapat ditingkatkan melalui penerapan metode overview, key ideas, read, record, recite, review dan reflect (OK5R).

\section{REFERENSI}

Aan Khasanah \& Isah Cahyani. 2016. Peningkatan Kemampuan Membaca Pemahaman Dengan Strategi Question Answer Relationships (QAR) Pada Siswa Kelas V Sekolah Dasar.Jurnal Pedagogik Sekolah Dasar.Jilid 4 No. 2.

Anas Sudjono. 2010.Pengantar Statistik Pendidikan. Jakarta: Rajawali Pers.

Annisa Mardhiyah, dkk. 2019. Penerapan Strategi OK5R (Overview, Key, Ideas, Read, Record, Recite, Review And Reflect Untuk Meningkatkan Kemampuan Membaca Pemahaman Siswa Di Kelas V Sekolah Dasar. Jurnal Pendidikan Guru Sekolah Dasar.Vol. 4 No.III.

Amirono dan Daryanto. 2016. Evaluasi \& Penilian Pembelajaran Kurikulum 2013. Yogyakarta: Gava Media.

Aprida Pane dan Muhammad Darwis Desopang. 2017.Belajar dan Pembelajaran.Jurnal Kajian Ilmu-Ilmu Keislaman.Vol. 03, N0.2.

Ariep Hidayat, dkk.2020.Metode Pembelajaran Aktif dan Kreatif Pada Madrasah Diniyah Takmiliyah Di Kota Bogor.Jurnal Pendidikan Islam.Vol. 09, No. 01.

Arwida Endah Zuhari, dkk. 2018.Penerapan Metode Guide Reading Untuk meningkatkan Kemampuan Membaca Pemahaman Siswa IV SD.Jurnal Pendidikan Guru Sekolah Dasar.Vol. III No.II.

Dasri.2017. Penerapan Strategi DRA (Directed Reading Activity) Untuk Meningkatkan Kemampuan Siswa Dalam Membaca Pemahaman.Jurnal Pendidikan Rokania, Vol. II, No. 3. ISSN 2527-6018 E-ISSN 2548-4141.

Dalman. 2013.Keterampilan Membaca. Jakarta: PT Rajagrafindo Persada.

Departemen Agama RI. 2006.Qur'an Tajwid dan Terjemahannya. Jakarta: Magfirah Pustaka.

Delima Simanjuntak. 2017. Penerapan Strategi Directed Reading Activity (DRA) Untuk Meningkatkan Kemampuan Membaca Pemahaman Kelas V SDN 003 Pagaran Tapah Darussalam Kabupaten Rokan Hulu. Jurnal Primary Program Studi Pendidikan Guru 
Sekolah Dasar Fakultas Tarbiyah dan Ilmu Pendidikan Universitas Riau, Vol. 6, No. 1 April-September.

Desriana Sovia dan Nursalim.2020. Meningkatkan Aktivitas Belajar Bahasa Indonesia Melalui Model Pembelajaran Pertemuan Kelas Pada Siswa Kelas V SDN 3 Pekanbaru.El-Ibtidaiy: Journal of Primary Education, Vol. 3, No. 1. p- ISSN: 2620-325, e-ISSN: 2615-6121.

Farida Rahim. 2011. Pengajaran Membaca di Sekolah Dasar.Jakarta: Bumi Aksara.

Hasni Suciawati 2018. Kemampuan Komunikasi Siswa Terhadap Membaca Intensif Siswa Pada Mata Pelajaran Bahasa Indonesia Dengan Strategi PQ4R Di Kelas V SD Negeri 067852 Titi Kuning Medan.Jurnal Pengembangan Ilmu Komunikasi dan Sosial, Vol. 2, No.1.

Hidayatul Alawiyah dan Melly Andriani.2020. Meningkatkan Kemampuan Pemecahan Masalah pada Pelajaran Matematika Melalui Strategi Pembelajaran Peningkatan Kemampuan berpikir Siswa Kelas IV Madrasah Ibtidaiyah Al Wathaniyah Tualang Kecamatan Tualang Kabupaten Siak.El-Ibtidaiy: Journal of Primary Education, Vol. 3, No. 2. p-ISSN: 2620-3251, e-ISSN:2615-6121.

Intan Nurhidayah, dkk.2017. Penerapan Model Pembelajaran Kooperatif Tipe CIRC Untuk Meningkatkan Kemampuan Membaca Pemahaman.Jurnal Pendidikan Guru Sekolah Dasar, Vol. II No. 1V.

Istarani. 2012.Kumpulan $\quad 40 \quad$ Metode Pembelajaran.Medan: Media Persada.

Mardiah KalsumNasution. 2017.Penggunaan Metode Pembelajaran dalam Peningkatan Hasil Belajar Siswa. Jurnal Ilmiah Bidang Pendidikan. Vol. 11, No. 1.

Muhafidin.2016. Pembelajaran Membaca Pemahaman Pada Siswa Kelas V SD Negeri 1 Cidempet Kecamatan Arahan Kabupaten Indramayu.Jurnal Profesi Pendidikan Dasar. Vol.3 No. 1, Juli. E-ISSN: 2503-3530.

Nirmala Sari.Kemampuan Membaca Pemahaman Melalui Model Pembelajaran Pair Check Siswa Kelas VIII SMP Negeri 10 Kota Palopo.Jurnal Onoma: Pendidikan, Bahasa dan Sastra PBSI FKIP Universitas Cokroaminoto Palopo.Vol. 3, No. 1.ISSN 2443-3667.

Nurul Hidayah dan Fiki Hermansyah. 2016. Hubungan Antara Motivasi Belajar Dan Kemampuan Membaca Pemahaman Siswa Kelas V Madrasah Ibtidaiyah Negeri 2 Bandar Lampung Tahun 2016- 2017.Jurnal Pendidikan dan Pembelajaran Dasar. Vol. 3, No. 2

Desember 2016.p-ISSN: 2355-1925.

Nursalim. Samsi Hasan. 2014.Bahasa Indonesia.Pekanbaru: Kreasi Edukasi.

Risma Amalia Rahayu, dkk. 2018. Keterampilan Membaca Pemahaman dengan Metode PQ4R (Preview, Question, Read, Reflect, Recite,Review) Siswa Sekolah Dasar Kelas Tinggi.Jurnal Pendidikan Guru Sekolah Dasar.Vol.III, No.II.

Sahati Kaban dan Tria Rutmila. 2015.Peningkatan Kemampuan Membaca Pemahaman Melalui Pendekapan Saintific Pada Siswa Kelas V SD Negeri Pondok Labu 12 Pagi Jakarta Selatan.Jurnal Ilmiah PGS.Vol. VIII, No. 2.

Samiudin. 2016.Peran Metode untuk Mencapai Tujuan Pembelajaran.Jurnal Studi Islam.volume 11, No. 2.

Samsu Somadayo. 2011.Strategi dan Teknik Pembelajaran Membaca.Yogyakarta: Graha Ilmu.

Saprun.2020. Penerapan Metode Pembelajaran Sosiodrama dalam Meningkatkan Motivasi Belajar Siswa Pada Mata Pelajaran IPS Kelas III di Madrasah Ibtidaiyah Raudhlatussybyan 
NW Belencong Kecamatan Gunungsari.Jurnal Prodi PGMI.Vol. 5, No. 1.p-ISSN 2502504X.

Saryi. 2007. Penggunaan metode OK5R dalam Meningkatkan Kemampuan Membaca Siswa Kelas X MAN 1 Bogor. Skripsi S1 Fakultas Keguruan Ilmu Pendidikan, UNPAK Bogor.

Suid AB, dkk. 2016.Pengaruh Metode Pembelajaran Inkuiri Pada Subtema Gerak Dan Gaya Terhadap Hasil Belajar Siswa Kelas IV SDN 16 Banda Aceh.Jurnal Pesona Dasar.Vol. 3, No. 4.

Suslawati. 2019. Media Gambar Dapat Meningkatkan Hasil Belajar Matematika Siswa Pada Tema Pembelajaran Keluarga Kelas I SD Negeri 004 Rokan IV Koto tahun Pelajaran 2015/2016. Indonesian

Journal of Basic Education.Vol 2, No 1.p-ISSN 2615-5796.

Wijaya Kusumah dan Dedi Dwitagama. 2010. Mengenal Penelitian Tindakan Kelas, Ed.2. Jakarta: Permata Puri Media.

Zainal Aqib. 2009. Penelitian Tindakan Kelas. Bandung: Yrama Widya. 